What Happened to the Nordic Model for International Peace and Security?

Wivel, Anders

Published in:

Peace Review

DOI:

10.1080/10402659.2017.1381521

Publication date:

2017

Document version

Peer-review version

Citation for published version (APA):

Wivel, A. (2017). What Happened to the Nordic Model for International Peace and Security? Peace Review, 29(4; Peace Journalism), 489-496. [9]. https://doi.org/10.1080/10402659.2017.1381521 


\title{
What happened to the Nordic model for international peace and security?
}

\author{
Anders Wivel
}

Published in Peace Review 29(4): 489-496. Final draft.

The Nordic countries have long been renowned for their contribution to international peace and security. This contribution - occasionally viewed by both Nordic and non-Nordic policy-makers and academics as a particular model for facilitating peace and development in international affairs is based on a combination of active contributions to peaceful conflict resolution, a high level of development aid and a continuous commitment to strengthening international society. However, recently Scandinavians have been making headlines for reasons that seem to contrast with their well-established brand as humane internationalist peacemakers.

In early 2016, Sweden, unofficial leader of the Nordic UN bloc during its golden Cold War years and champion of humane internationalism closed its border to Denmark to stop the influx of refugees and migrants thereby providing a strong contrast to its image as a North European haven for persecuted people all over the world. In January 2017, The New York Review of Books reported that Sweden's National Defense Radio Establishment (FRA) was viewed by the US National Security Agency (NSA) as one of its most valued foreign partners. FRA cooperates closely with the NSA on its hacking and cyberwarfare project, Quantum. In 2015, the leader of the nationalist Finns Party, a party unified in opposing the Ottawa Treaty banning anti-personnel mines, took up the position as Foreign Minister and Deputy Prime Minister in Finland. Denmark and Norway have 
established a reputation for military activism, often in close partnership with the United States. Both countries were part of the coalition of the willing Iraq in 2003 and between them they fired more than twenty percent of NATO's bombs against Muammar Gaddafi in the 2011 Libya intervention. What has happened to the Nordic model for international peace and security and why? In order to answer this question, I discuss the characteristics and origins of the Nordic model for international peace and security and identify three developments that has changed this model before proposing a potential way forward for a continued value based Nordic influence on international affairs.

The Nordic model for international peace and security has three characteristics. The first characteristic is activism. The Nordic countries seek actively to influence regional and global agendas on international peace and security. Activism is multi-dimensional involving military, economic and diplomatic means and mimics intra-Nordic cooperation by its reliance on a combination of government, civil society and international organizations. Also, policy activism has traditionally been a corollary of the Scandinavian welfare state viewing the ability to meet societal challenges as a collective responsibility rather than something to be grabbled with by the individual. Second, the policy content of this activism is value based. Welfare state values serve as the basis for domestic policy-making as well as foreign policy-making. These values include egalitarianism, peaceful conflict resolution, rule of law and collectivism as opposed to maximizing the interests of the individual state or human being at the expense of domestic or international society. Finally, the Nordic model for international peace and security is well-endowed and well-organized allowing the Nordic countries to take a leading role in developing and shaping UN policies on development and peacekeeping and to build a brand (during the Cold War in particular) as champions of decolonization, disarmament, human rights and global equality. The Nordic countries have used their effective public administrations underpin their foreign policy agenda, e.g. by acting as 
international mediators and problem-solvers and placing their nationals in central positions in international organizations. The strong and stable economies of the Nordic countries have allowed them to put their money, where their mouth is. In 1975 Sweden was the first country in the world to reach the UN target of investing 0.7 percent of GNI (until 1993 GNP) in official development assistance and this was followed by Norway in 1976 and Denmark in 1978.

The Nordic model for international peace and security has roots in nineteenth century 'Scandinavism', a romantic movement stressing Nordic 'brotherhood' and taking its inspiration from German and Italian nationalism. However, in contrast to these movements, the goal was not state-building, but the creation of a Scandinavian civil society. Inspired by cultural figures such as Danish poet and protestant priest N.F.S. Grundtvig, Scandinavists stressed the shared history of the Nordic peoples as well as common values, most notably a combination of political liberalism and economic equality, which came to influence both peasant and labor movements in the Nordic countries from the late nineteenth century. Rather than an alternative to national state-building, the idea of the Nordic became integral to national identity construction.

Scandinavian identity construction shared many similarities with parallel developments in other parts of Europe, but it departed in two ways. First, the Nordic region was more peaceful than other regions. Like other regions there was plenty to fight about: The breaking up of states, linguistic and cultural minorities and disputes over resources and borders, but unlike other regions this did not lead to war. There has been no armed conflict between Nordic countries since 1815 . From the early twentieth century, peaceful coexistence was not only a characteristic of the region but an explicit foreign policy goal and part of the Nordic 'brand'. The Nordic Association of Civil Associations ('Foreningen Norden'), established in 1919 saw the promotion of peaceful coexistence and cooperation as primary goals. Initially, an elitist project among university students in Sweden, Denmark and Norway, it soon expanded its membership base to large segments 
of the population in these three countries as well as Finland, Iceland, Greenland, the Faroe Islands and the Aaland Islands. The Scandinavian conception of peaceful coexistence shared more affinities with the post-Cold War broad security agenda than with the narrow focus on military security of the time, and the ideas nurtured in the association came to serve as a precursor for both Nordic Cold War activism and intra-Nordic 'cobweb integration', a combination of bottom-up and top-down initiatives from various combinations of public, private and third sector actors taking place under the auspices of the Nordic Council from 1952. Second, from the 1930s, all five Nordic states developed welfare states based on broad societal compromises between labor and employer representatives. Although the welfare state was not unique to Scandinavia, the Nordic model stood out by its commitment to consensual and corporatist decision-making and its universal provisions for welfare, health and education. Furthermore, the strong emphasis on seeing actions and actors embedded in a community of equals sharing responsibility for the wellbeing of all, gradually led to policies promoting gender equality and environmentalism.

The international expression of these domestic policies was a Nordic model of 'humane internationalism' focusing on peaceful conflict resolution, global equality and support for international society embodied by institutions such as the United Nations. The Nordic model was characterized by its form as well as by its content. Nordic policy-makers were not shy to use their own region as a benchmark for a better world. They branded Scandinavia as a region with a unique set of qualities related to peacefulness and welfare state values: different from and better than the rest of Europe, let alone the world. The Nordic countries did not view themselves as exponents of either the Communist East or the Capitalist West, but as a 'Third Way' providing an alternative to both models. At the same time, frequent intra-Nordic consultations underpinned information sharing and common positions. These consultations had begun during the First World War, when the foreign ministers of Denmark, Sweden and Norway met on a regular basis and were 
strengthened after the war, with the League of Nations providing a multilateral framework and platform for Nordic activism. Subsequently, these experiences served as a point of departure for an elaborate system of Nordic consultations and cooperation in the United Nations and more recently the European Union, although there has been a shift from substantial cooperation and towards information sharing.

What has happened to this Nordic model for international peace and security? Consultations between Nordic diplomats are still frequent, having seen a resurgence in the context of the European Union. Yet, anyone trying to identify a Nordic model for international peace and security today would be hard pressed. This is not because traditional Nordic priorities have disappeared from official foreign policy discourse but rather because it now co-exists with other sometimes contrasting - priorities. War participation without a UN mandate and cyber war cooperation with the NSA seems to go hand in hand with traditional Nordic priorities such as peace mediation and promotion of human rights. And anyone trying to measure the foreign policies of the Nordic countries today against the yardstick of the old model would find a number of puzzling contradictions to Cold War policies promoting human rights, peacebuilding and détente, environmentalism and global equality. Three developments help explaining what has happened to the Nordic model.

First, an immediate effect of the end of the Cold War was that the Nordic region lost the privileged position it had occupied during the superpower conflict. Benefitting from a Nordic security community and arguing that the security of the individual Nordic countries was tied to together in a security complex, they argued the existence of a particular 'Nordic balance', i.e. that the relative low tension in the Nordic area depended upon the restraint of the two superpowers, and that any attempt by one of them to increase influence in the area and limit Nordic action space could have serious consequences for European security. With the collapse of the Soviet Union, the Nordic 
countries needed to reorient their security policies. Sweden and Finland moved towards the European Union (EU), while Norway and Denmark worked hard to prove their worth within NATO and nurture their relationship with the US superpower. This had the long-term effect of driving Nordic security policies apart, and resulted in a reorientation of Danish - and to a lesser extent Norwegian - defense towards expeditionary forces and a stronger focus on providing hard security equipment and troops for international military missions (also as a measure of success) at the expense of traditional Nordic priorities.

Second, the development of the EU as a foreign policy actor has at the same time provided a stronger platform for promoting Nordic preferences and a melding of European and Nordic practices, which both moderated the Nordic position and made it less visible outside diplomatic circles. Some of the traditional Nordic priorities on human rights and peacebuilding are now also European priorities and seen as key for strengthening the international influence of the EU. To some extent 'normative power Europe' has replaced the Scandinavian norm-entrepreneurs as a point of reference for promoting human rights and development. This development provides new avenues for influence on European and international politics, but it also embeds Nordic influence on international peace and security in the traditional politics of bargaining and national interest that the Nordics previously sought to be different from and better than. The Nordic approach to international peace and security is no longer an alternative to European power politics but an integral part of it.

Third, the less restrictive security environment of the past decades has resulted in a democratization and politicization of Nordic foreign and security policies. Debating foreign and security policy and Scandinavia's position in world politics is no longer the prerogative of the political elite. Foreign and security policy priorities are now part of the general political debate, and consequently the allocation of money for these priorities is often in direct competition with the 
allocation of money for other policy areas. Moreover, the rise of political actors such as the Sweden Democrats in Sweden, the Progress Party in Norway, the True Finns in Finland and the Danish People's Party in Denmark are examples of new populist sentiments in the Nordic electorates questioning old dogmas of the elite on migration and development aid and advocating a policy shift away from liberal-social democratic practices.

The Nordic brand as a positive and progressive force for international peace and security remains strong. When US President Barack Obama hosted a state dinner for the Finnish president and the prime ministers from Sweden, Norway, Denmark and Iceland in May 2016, he stressed their ability to "punch above their weight. In their values, in their contributions, not just to making their own countries function well, but to make the whole world a better place makes them one of our most valuable partners everywhere in the world." This assessment corresponds well to the high rankings of the Nordic countries in such surveys as the Global Peace Index, the Global Presence Index and the annual Soft Power Survey. However, as with any other brand, it will be difficult to maintain, if the quality of the 'product' is gradually eroded. More importantly, the Nordic model for international peace and security has served the Nordic countries well as a platform for influence and as a frame of reference for who they are, and what they want to do. What should the Nordic countries do to maintain and increase a positive influence on the world in accordance with the interests and values?

Sweden's feminist foreign policy offers one potential way forward. Viewing gender equality and the advancement of basic human rights for women as both an obligation and a prerequisite for achieving more general foreign policy objectives such as peace, security and sustainable development, it allows for a rethinking as well as a rebranding of the Nordic model. 
Swedish feminist foreign policy encompasses some of the same qualities as the Cold War Nordic model for international peace and security. It is based on values of equality and collective responsibility and starts from a broad and multidimensional understanding of security. Like the Nordic model for international peace and security, feminist foreign policy builds on specific characteristics and strengths of the Nordic societies and applies ideas and policy solutions already tested in the Nordic countries. Consequently, it has provided the basis for Nordic cooperation, i.e. the proposal by Sweden, Finland and Denmark to establish a high-level position in the European External Action Service for the promotion of gender equality. As noted by Swedish Foreign Minister Margot Wallström, Sweden's feminist foreign policy has at its core four words beginning with the letter ' $\mathrm{R}$ ': Reality check (getting the facts right in order to provide a basis for finding solutions including 100 percent of the population), rights (promoting women's rights as human rights), resources (applying a gender perspective when distributing aid and other resources) and representation (making sure women are part of the decision-making process at all levels).

From this point of departure feminist foreign policy would allow the Nordic states to address the weaknesses of the Nordic model following from the changes discussed above. It could provide a compass for the Nordic countries, when they react to developments in international institutions such as the EU, NATO and the UN anchoring their reactions in values deeply embedded in their societies and at the same time serve as an ideational platform for new Nordic initiatives internationally. Also, gender equality is recognized across the political spectrum in the Nordic countries as a value that serves as the basis of society (although not always fully implemented). For this reason, it could serve as a starting point for foreign policy debates reaching beyond the traditional foreign policy elite in the Nordic countries, while at the same time providing a distinct Nordic voice internationally. 
The Nordic model for international peace and security was always an ideal type which in practice appeared more pragmatic and less progressive than what was signaled by its brand. During the Cold War, Sweden had contingency plans for welcoming US Marines in the case of Soviet attack. Despite the country's high profile neutrality and advocacy of a 'Third Way' between the two Cold War alliances, NATO officials considered Sweden a shadow member of the alliance. Denmark and Norway followed the Swedish lead on East-West détente and global equality, but with a pragmatic approach designed not to offend any of the two superpowers. Both countries used the particular Nordic ideological position and geopolitical location to expand their action space within NATO, most importantly by avoiding the stationing of US troops and nuclear weapons on Danish or Norwegian territory. One important exception was Greenland, home of the US Thule base, which Denmark used as a bargaining chip in its relationship with the US superpower. Finland and Iceland, restricted in their action space by their geopolitical locations, were only occasionally exponents of the Nordic model, e.g. none of them reached the UN ODA/GNI target during the Cold War.

In the decades following the collapse of the Soviet Union and the end of the Cold War, the Nordic model for international peace and security has been eroded by global, European and domestic developments. The migration policies and military polices of the Nordic countries often seem to contradict rather than to underpin a world based on equality and peaceful conflict resolution. Nordic consultations on international issues are more often a hub for exchanging information than a platform for joint action. Nordicity, once a powerful tool in the individual foreign policies of the Nordic states, is all but abandoned. In sum, the brand lives on, but the 'product' is no longer a distinct and progressive voice in international relations. However, Sweden's feminist foreign policy presents an original reformulation of a Nordic approach based on values that 
the Nordics view both as valuable in their own right and as useful for creating a more just and secure world. Will the other Nordic states follow suit?

Anders Wivel is a Professor in the Department of Political Science, University of Copenhagen, He researches and writes on small state security, the Nordic countries in international relations and power politics.

\section{Recommended readings}

Archer, Clive 2014. "The Nordic states and security”, in Clive Archer, Alyson J. K. Bailes and Anders Wivel (eds.), Small States and International Security: Europe and beyond. Routledge, London: 95-112.

Browning, Christopher S. 2007. "Branding Nordicity: Models, Identity and the Decline of Exceptionalism." Cooperation and Conflict 42(1): 27-51.

Ingebritsen, Christine 2002. "Norm entrepreneurs: Scandinavia's role in world politics." Cooperation and Conflict 37(1): 11-23.

Laatikainen, Katie Verlin 2003. “Norden's Eclipse The Impact of the European Union's Common Foreign and Security Policy on the Nordic Group in the United Nations." Cooperation and Conflict 38(4): 409-441.

Kuisma, Mikko 2007. "Social democratic internationalism and the welfare state after the 'golden age'." Cooperation and Conflict 42(1): 9-26. 
Mouritzen, Hans 1995. “The Nordic Model as a Foreign Policy Instrument: Its Rise and Fall.” Journal of Peace Research 32(1): 9-21.

Obama, Barack (2016) 'Full transcript of President Obama's toast at the Nordic State dinner', Washington Post, May 13, 2016, Located August 14, 2016 at https://www.washingtonpost.com/news/reliable-source/wp/2016/05/13/full-transcript-ofpresident-obamas-toast-at-the-nordic-state-dinner/ (accessed January 13, 2017).

Schouenborg, Laust 2013. The Scandinavian International Society: Primary institutions and binding forces, 1815-2010. London: Routledge.

Strang, Johan 2016. (ed.) Nordic Cooperation: A European region in transition. London: Routledge.

Wallström, Margot 2015. "Speech by the Minister for Foreign Affairs at Helsinki University”, March 3, 2015. Stockholm: Government Offices of Sweden, http://www.government.se/speeches/2015/03/speech-by-margot-wallstrom-at-helsinkiuniversity/ (accessed on January 12, 2017).

Wæver, Ole 1992. "Nordic Nostalgia: Northern Europe after the Cold War." International Affairs 68(1): 77-102.

Wivel, Anders 2013. "Birds of a feather flying apart? Explaining Nordic dissonance in the (post)unipolar world," in Ann-Sofie Dahl and Pauli Järvenpää (eds.), Northern Security and Global Politics: Nordic-Baltic strategic influence in a post-unipolar world. Routledge, London: 79-92. 